\title{
Genetic Engineering for Viral Disease Management in Plants
}

\author{
Shabir Hussain WANI, Gulzar S. SANGHERA \\ Punjab Agricultural University, Department of Plant Breeding and Genetics, 141004 \\ Ludhiana, India; shabirhussainwani@gmail.com (corresponding author)
}

\begin{abstract}
Viral diseases are a major threat to world agriculture and breeding resistant varieties against these viruses is one of the major challenge faced by plant virologists and biotechnologists. The development of the concept of pathogen derived resistance gave rise to strategies ranging from coat protein based interference of virus propagation to RNA mediated virus gene silencing. Much progress has been achieved in protecting plants against these RNA and DNA viruses. In this review, the most recent transgene based approaches for viral disease management in plants will be discussed.
\end{abstract}

Keywords: viral diseases, RNA viruses, DNA viruses, transgene, RNA interference, coat protein

Viruses are very widespread in nature, and they cause severe diseases and yield losses in economically important plants. Plant viruses can cause severe damage to crops by substantially reducing vigor, yield, and product quality. Losses of several billion dollars are reported annually in vegetable and fruit crops. Viruses that infect plants differ in particle morphology, type of genome and several other characteristics based on which they are classified. The most important characteristic feature of a virus is its genome. There are examples of viruses containing double stranded DNA (ds DNA, eg. Caulimovirus), single stranded DNA (ssDNA eg. Geminivirus) double stranded RNA (dsRNA eg. Reoviridae) and single stranded RNA (ssRNA) with positive sense or negative sense genome (eg. Potyvirus). However, majority of plant viruses have genome consisting of RNA (Brunt et al., 1996). Management strategies for viral diseases are often directed essentially against vectors that spread viruses within and between fields. So far, the most effective approach to control viruses relies on the use of resistant cultivars and/or rootstocks. Host-resistance genes have been extensively exploited by traditional breeding techniques for the development of virus-resistant plants. However, host resistance has been identified for a few viruses only and a limited number of commercial elite crop cultivars and rootstocks exhibit useful resistance. Therefore, engineered resistance is attractive to complement conventional breeding approaches, in particular when resistant material with desired horticultural characteristics has not been developed successfully or when no host resistance sources are known. Actually, the deployment of virus-resistant transgenic plants has become an important strategy to implement effective and sustainable control measures against major virus diseases.
Generation of transgenic plants with virus resistance has been demonstrated as an effective strategy against virus infections through the expression of coat protein genes, viral replicase genes, or other viral sequences. This phenomenon is termed pathogen-derived resistance and includes protein-mediated resistance and RNA mediated resistance. The mechanism of RNA mediated resistance involves RNA silencing, in which sequence-specific RNA degradation occurs (Kawazu et al., 2009). Here in this review, the coat protein and RNAi mediated resistance for viral disease management will be discussed.

\section{Coat protein-mediated resistance (CP-MR)}

The most important agricultural application of Pathogen Derived Resistance (PDR) is coat protein mediated protection (CPMP) against plant virus diseases. The viral coat-protein gene transferred into plants makes them resistant to virus from which the gene for the coat protein (CP) was derived. This was first demonstrated for Tobacco mosaic virus (TMV) in tobacco (Powel-Abel et al., 1986). Coat Protein is required for systemic infection by monopartite geminiviruses (Rojas et al., 2001), and tomato plants expressing the $\mathrm{CP}$ of the monopartite begomovirus tomato yellow leaf curl geminivirus (TYLCV) exhibited delayed symptom development that was dependent on the expression levels of transgenic CP (Kunik et al., 1994).

In another attempt by Furutani et al. (2006), somatic embryos of Glycine max (L.) Merrill cultivar 'Jack' were co-transformed with coat protein $(\mathrm{CP})$ gene of attenuated isolates of soybean mosaic virus (SMV) and hygromycin phosphotransferase (hpt) gene by means of microprojectile bombardment. These transformed embryogenic tissues were selected in hygromycin-containing liquid medium. 
The hygromycin-resistant embryogenic tissues obtained through the selection were regenerated, and CP gene was detected in the 11 transgenic plants out of them. In order to assess their resistance to SMV, mechanical inoculation was performed in $T_{1}$ generation. The disease symptom was examined visually and confirmed by the enzyme-linked immunosorbent assay (ELISA). Finally, three independent lines highly resistant to SMV were obtained. This was the first report of the soybean plants that conferred a high resistance to SMV by the transformation with CP gene of the SMV attenuated isolates.

A transformation system of pepper was set up using Agrobacterium that had been transfected with the coat protein gene, CMVP0-CP, with the aim of developing a new CMVP1-resistant pepper line. A large number of transgenic peppers $\left(T_{1}, T_{2}\right.$ and $\left.T_{3}\right)$ were screened for CMVP1 tolerance using CMVP1 inoculation. Transgenic peppers tolerant to CMVP1 were selected in a plastic house as well as in the field. Three independent $T_{3}$ pepper lines highly tolerant to the CMVP1 pathogen were found to also be tolerant to the CMVP0 pathogen. These selected $\mathrm{T}_{3}$ pepper lines were phenotypically identical or close to the nontransformed lines. However, after CMVP1 infection, the height and fruit size of the non-transformed lines became shorter and smaller, respectively, while the T3 pepper lines maintained a normal phenotype (Lee et al., 2009)

The level of protection conferred by CP genes in transgenic plants varies from immunity to delay and attenuation of symptoms. In some cases protection is broad and effective against several strains of the virus from which the CP gene is derived, or even against closely related virus species (Lomonossoff, 1995). Molecular mechanisms that govern CP-mediated resistance (CPMR) are not fully understood, and furthermore, mechanisms of CPMR are different in different viruses (Bendahmane et al., 2007). Asurmendi et al. (2007) postulated that the state of aggregation of CPs is correlated with the level of CPMR. This suggested that CPMR may be mediated by certain configurations of quaternary structures rather than by the subunit perse. Bendahmane et al. (2007) further propose that the degree of regulation of replication by aggregates of CP determines the relative strength of CPMR. CPMR and other cases of PDR reviewed below are compatible with direct interference of these proteins with virus accumulation. However, the establishment of different levels of resistance indicates that multiple mechanisms could be involved. Furthermore, as will be discussed below, a transgene can confer both protein- and RNA-mediated protection. The attribution of resistance to expression of the viral protein or to its RNA is often posed as a 'dilemma'. Several explanations have been proposed to reconcile different and sometimes contrasting results. However, in spite of uncertainty about mechanisms, high levels or broad resistance may be attributed to co-existence of both proteinand RNA-mediated interferences.
A variety of yellow squash called 'Freedom 11' has been released in the USA. Several varieties of potato, cucumber and tomato, in which CP-MR has been used, are under field evaluation. Transgenic papaya resistant to papaya ring-spot virus (PRSV) has been developed and is being commercially grown in the USA. (Ferreira et al., 2002). Subsequently, virus-resistant transgenics have been developed in tomato, melon, rice, papaya, potato and sugarbeet (Tab. 1) (Fuchs and Gonsalves, 2007).

\section{$R N A$ interference mediated resistance}

Homology-dependent selective degradation of RNA, RNA-interference (RNAi) or Post-transcriptional gene silencing (PTGS) is involved in several biological processes, including adaptive defence against viruses in plants (Herr 2005; Ratcliffe et al., 1999; Vance and Vaucheret, 2001; $\mathrm{Yu}$ and Kumar, 2003). The first demonstration of RNAimediated virus resistance was shown by Waterhouse et al. (1998), against Potato virus Y (PVY) in transgenic tobacco plants. Resistance against PVY in transgenic tobacco plants expressing the PVY protease gene simultaneously in sense and anti-sense orientation was much higher than in lines expressing the same gene individually in either orientation. Antiviral RNAi technology has been used for viral disease management in human cell lines (Novina et al., 2002). Such silencing mechanisms (RNAi) can also be exploited to protect and manage viral infections in plants (Ullu et al., 2002; Waterhouse et al., 2001). The P1/HCPro suppressors from the potyvirus inhabited silencing at a step down stream of dsRNA processing, possibly by preventing the unwinding of duplex siRNAs, or the incorporation into RISC or both (Chapman et al., 2004). The utilization of RNAi technology has resulted in inducing immunity reaction against several other viruses in different plant-virus systems (Tab. 1). In phyto-pathogenic DNA viruses like geminiviruses non-coding intergenic region of Mungbean yellow mosaic India virus (MYMIV) was expressed as hairpin construct under the control of the $35 \mathrm{~S}$ promoter and used as biolistically to inoculate MYMIVinfected black gram plants and showed a complete recovery from infection, which lasted until senescence (Pooggin et al., 2003). RNAi mediated silencing of geminiviruses using transient protoplast assay where protoplasts were co-transferred with a siRNA designed to replicase (Rep)coding sequence of African cassava mosaic virus (ACMV) and the genomic DNA of ACMV resulted in 99\% reduction in Rep transcripts and 66\% reduction in viral DNA (Vanitharani et al., 2003). It was observed that siRNA was able to silence a closely related strain of ACMV but not a more distantly related virus.

About more than 40 viral suppressors have been identified in plant viruses (Ruiz and Voinnet, 2007). Results from some of the well-studied virus suppressors indicated that suppressors interfere with systemic signaling for silencing (Mlotshwas et al., 2002). During last few years, the $p 69$ 
22

encoded by Turnip yellow mosaic virus has been identified as silencing suppressors that prevented host RDR-dependent secondary dsRNA synthesis (Chen et al., 2004).P14 protein encoded by aureus viruses suppressed both virus and transgene-induced silencing by sequestering both long dsRNA and siRNA without size specificity (Merai et al., 2005). Multiple suppressors have been reported in Citrus tristeza virus where $p 20$ and coat protein $(C P)$ play important role in suppression of silencing signal and $p 23$ inhibited intracellular silencing Multiple viral components, viral RNAs and putative RNA replicase proteins were reported for a silencing or suppression of Red clover necrotic mosaic virus (Takeda et al., 2005). In this case, the RNA silencing machinery deprived of DICER-like enzymes by the viral replication complexes appears to be the cause of the suppression. Pns10 encoded by Rice dwarf virus suppressed local and systemic S-PTGS but not IR-PTGS suggesting that Pns 10 also targets an upstream step of dsRNA formation in the silencing pathway (Cao et al., 2005). Niu et al.
(2006) used a 273-bp (base pair) sequence of the Arabidopsis miR159 a pre-miRNA transcript expressing amiRNAs against the viral suppressor genes P69 and HC-Pro to provide resistance against Turnip yellow mosaic virus and Turnip mosaic virus infection, respectively. In addition, a dimeric construct harboring two unique amiRNAs against both viral suppressors conferred resistance against these two viruses in inoculated Arabidopsis plants. Similarly, Qu et al. (2007) used a different amiRNA vector to target the $2 \mathrm{~b}$ viral suppressor of the Cucumber mosaic virus (CMV), a suppressor that interacted with and blocked the slicer activity of $A G O 1$ had also shown to confer resistance to $\mathrm{CMV}$ infection in transgenic tobacco. A strong correlation between virus resistance and the expression level of the $2 \mathrm{~b}$-specific amiRNA was shown for individual plant lines.

It is evident from above-mentioned reports that the RNA components, such as single strand template RNA, dsRNA and/or siRNA of the silencing pathways are the

Tab. 1 RNAi mediated approach for plant virus management

\begin{tabular}{|c|c|c|c|}
\hline Target plant & Virus & Targeted region & References \\
\hline Barley, wheat & Barley stripe mosaic virus & pds & Holzberg et al., 2002; Scofield et al., 2005 \\
\hline Barley, rice, maize & Brome mosaic virus & $\begin{array}{l}\text { pds, actin } 1, \\
\text { rubisco activase }\end{array}$ & Ding et al., 2006 \\
\hline Rice & Rice yellow mottle virus (RYMV) & $\begin{array}{l}\text { RYMV (wt.CP) } \\
\text { and }(\Delta \text { NLS.CP })\end{array}$ & Kouassi et al., 2006 \\
\hline Rice & Rice tungro bacilliform virus (RTBV) & $R T B V-O s, R T B V-O-D s$ & Tyagi et al., 2008 \\
\hline Arabidopsis & Cabbage leaf curl virus & $g f p, C H 42, p d s$ & Turnage et al., 2002 \\
\hline P.sativum & Pea early browning virus & pspds, uni,kor & Constantin et al., 2004 \\
\hline $\begin{array}{l}\text { N. benthamiana, } \\
\text { M. esculenta }\end{array}$ & African cassava mosaic virus & $p d s, s u, c y p 79 d 2$ & Fofana et al., 2004 \\
\hline$N$. benthamiana & Poplar mosaic virus & gfp & Naylor et al., 2005 \\
\hline N. benthamiana, S. tuberosum & Potato virus $\mathrm{X}$ & $p d s, g f p$ & $\begin{array}{l}\text { Ruiz et al., 1998; Faivre- } \\
\text { Rampant et al., } 2004\end{array}$ \\
\hline N.benthamiana & Turnip crinkle virus & TCV-cp & Vasudevan et al., 2008 \\
\hline Nicotiana tabacum & Satellite tobacco mosaic virus & Several genes & Gossele et al., 2002 \\
\hline N. benthamiana, N. tabacum & Tobacco mosaic virus & $p d s, p s y$ & Kumagai et al., 1995 \\
\hline $\begin{array}{l}\text { N. benthamiana, Arabidopsis, } \\
\text { tomato, Solanum species, Chilli } \\
\text { pepper, opium poppy, Aquilegia }\end{array}$ & Tobacco rattle virus & $\begin{array}{l}\text { Rarl, EDS1, NPRI/ } \\
\text { NIM1,pds, rbcS, gfp }\end{array}$ & $\begin{array}{l}\text { Liu et al., 2002b; Ratcliff et al., } \\
\text { 2001; Brigneti et al., 2004; Chung } \\
\text { et al., 2004; Hileman et al., } 2005 \text {; } \\
\text { Gould and Kramer, } 2007\end{array}$ \\
\hline$N$. benthamiana & Tomato bushy shunt virus & gfp & Hou and Qiu, 2003 \\
\hline N. benthamiana & Tomato golden mosaic virus & $s u, l u c$ & Peele et al., 2001 \\
\hline $\begin{array}{c}\text { N. benthamiana, } \\
\text { Lycopersicon esculentum } \\
N . \text { glutinosa, N. tabacum }\end{array}$ & $\begin{array}{l}\text { Tomato yellow leaf curl China } \\
\text { virus-associated b DNA satellite }\end{array}$ & $p c n a, p d s, s u, g f p$ & Tao and Zhou, 2004 \\
\hline N. benthamiana & $\begin{array}{l}\text { Grapevine leafroll-associated virus-2 } \\
\text { (GLRaV-2) }\end{array}$ & GLRaV-2 -cp & Ling et al., 2008 \\
\hline Citrus & Citrus psorosis virus (CPsV) & $\mathrm{CPsV-cp}$ & Zenek et al., 2008 \\
\hline N. benthamiana & Grape vine A & GVA-minireplicon & Brumin et al., 2009 \\
\hline Potato & Potato virus $\mathrm{X}$ and Potato virus $\mathrm{Y}$ & PVX-cp, PVY-Nib & Bai et al., 2009 \\
\hline Lettuce & Mirafiori lettuce virus MiLA & Ir-MiLA & Kawazu et al., 2009 \\
\hline Pepper & Cucumber mosaic virus(CMV) & CMVP0-CP & Lee et al., 2009 \\
\hline Lycopersicon esculentum & Tomato leaf curl virus (ToLCV) & $\mathrm{AC} 4$ & Praveen et al., 2010 \\
\hline
\end{tabular}


preferred targets of most viral suppressors. However, plant viruses are known to have evolved a counter-silencing mechanism by encoding proteins that can overcome such resistance (Díaz-Pendón and Ding, 2008; Li, 2006; Ding, 2006). These suppressors of gene silencing are often involved in viral pathogenicity, mediate synergism among plant viruses and result in the induction of more severe disease. Simultaneous silencing of such diverse plant viruses can be achieved by designing hairpin structures that can target a distinct virus in a single construct (Díaz-Pendón and Ding, 2008). Transgenic lettuce with resistance to big-vein disease was produced by introducing an antisense construct of the Lettuce big-vein associated virus $\mathrm{LBVaV}$ $\mathrm{CP}$ gene. The transgenic lettuce showed resistance not only to LBVaV but also to MiLV and big-vein symptoms expression (Kawazu et al., 2006).
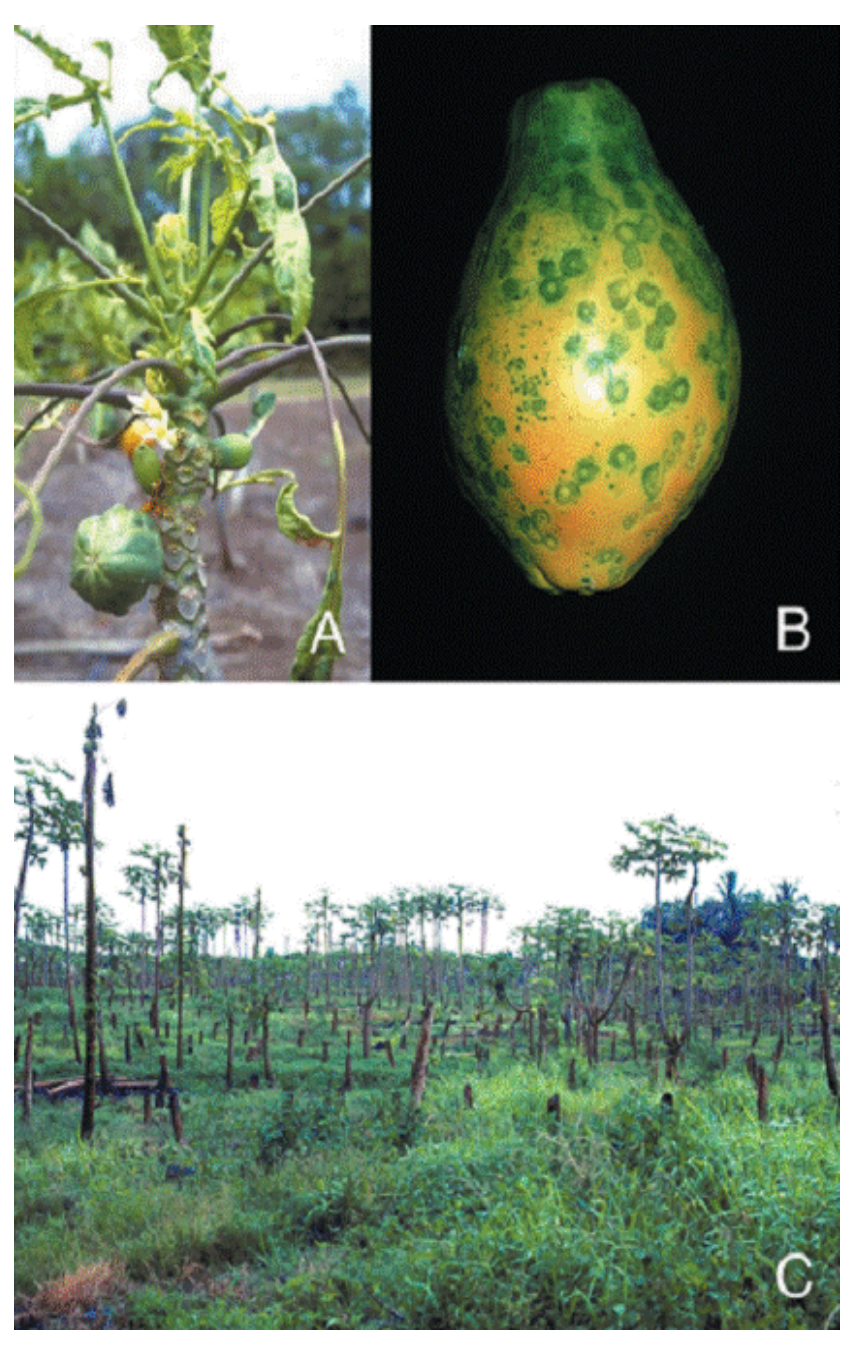

Fig. 1. Fig. 1. Symptoms of PRSV on papaya: PRSV-infected papaya tree; (B) ringspot symptoms on fruit; (C) PRSV-infected papaya orchard in Puna area of Hawaii in 1994 (Tripathi et al., 2008)
Papaya Ringspot Virus resistance (coat protein and gene silencing approach)

Papaya is one of the most important cash crops in the tropics and subtropics. However, the production of this economically important fruit crop is limited by the destructive disease caused by the Papaya ringspot virus (PRSV) (Bau et al., 2008) and the fragile and perishable fruit traits unfavorable for large-scale exportation make papaya lag far behind banana and pineapple in the world market.

PRSV is a member of the genus Potyvirus (Murphy et al., 1995), is transmitted nonpersistently by aphid, and is sap-transmissible in nature. PRSV genome contains a single-stranded positive sense RNA of about $40 \mathrm{~S}$ (Yeh and Gonsalves, 1985). Strains of PRSV from Hawaii (Yeh et al., 1992) and Taiwan (Wang and Yeh, 1997) have been completely sequenced, both containing 10.326 nucleotides in length. In papaya, PRSV causes severe mosaic and distortion on leaves, ringspots on fruits, and watersoaking oily streaks on upper stems and petioles (Fig. 1). It stunts the plant and drastically reduces the size and the quality of the fruit. In order to solve the problems caused by PRSV, in the late 1980s the group of Gonsalves at Cornell University and Hawaii started a research project to develop transgenic papaya. Ling et al. (1991) first demonstrated that the expression of the PRSV HA 5-1 CP gene in tobacco affords a broad-spectrum protection against different potyviruses.

However, effective gene transfer systems require reliable and efficient procedures for plant regeneration from cells. Fitch and Manshardt (1990) reported that somatic embryogenesis from immature zygotic embryos of papaya can be integrated into a useful gene transfer technology. By the same year, Fitch et al. (1990) successfully incorporated the CP gene of HA 5-1 into papaya via microprojectile bombardment and obtained plants resistant to infection by the severe Hawaii HA strain. Among their transgenic papaya lines, line 55-1 was virtually immune to infection by HA.

\section{Transgenic papaya in Hawaii}

The plants of transgenic papaya line 55-1 are highly resistant to Hawaiian PRSV isolates under greenhouse and field conditions (Lius et al., 1997). The resistance is triggered by the posttranscriptional gene silencing (PTGS) -an RNA-mediated specific degradation process of innate nature of plants against pathogens (Gonsalves 2002; Hamilton and Baulcombe, 1999). However, the characteristic of sequence homology-dependent resistance limits the application of CP-transgenic papaya for controlling PRSV in other geographic regions other than Hawaii (Gonsalves, 2002). The field trial of the homozygous line SunUp and hemizygous line Rainbow indicates that both of them offer a good solution to the PRSV problem in Hawaii (Ferreira et al., 2002). This was the first successful case 


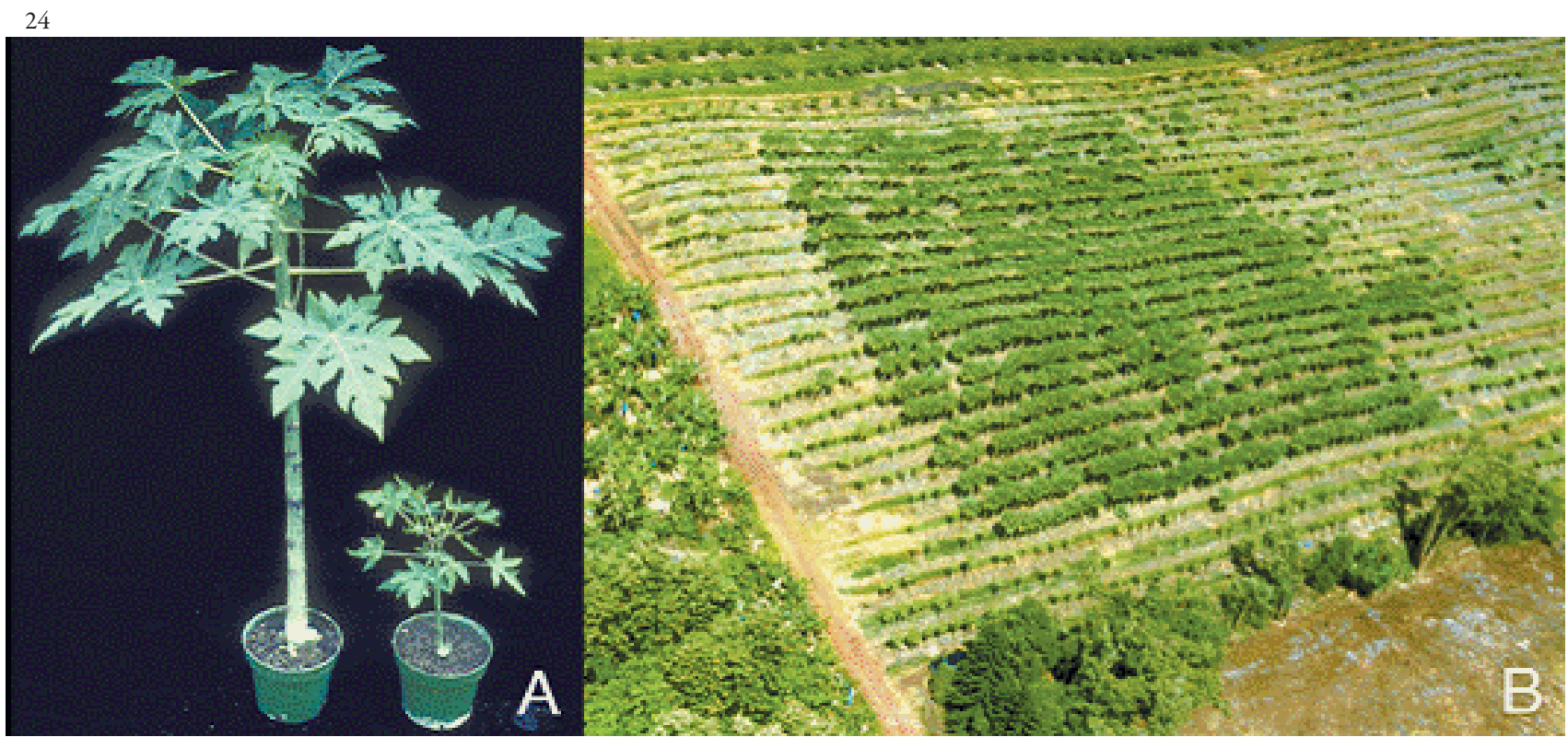

Fig. 2. Evaluation of transgenic papaya for PRSV resistance. (A) R0-transgenic papaya line 55-1 (left) and nontransgenic control (right) six months after inoculation with PRSV HA in the greenhouse. (B) Aerial photograph of the 1-acre plot of Rainbow papaya in Puna (Hawaii) 28 months after transplanting. The Rainbow block was surrounded by non-transgenic susceptible Sunrise plants, which are severely infected by PRSV (Tripathi et al., 2008)

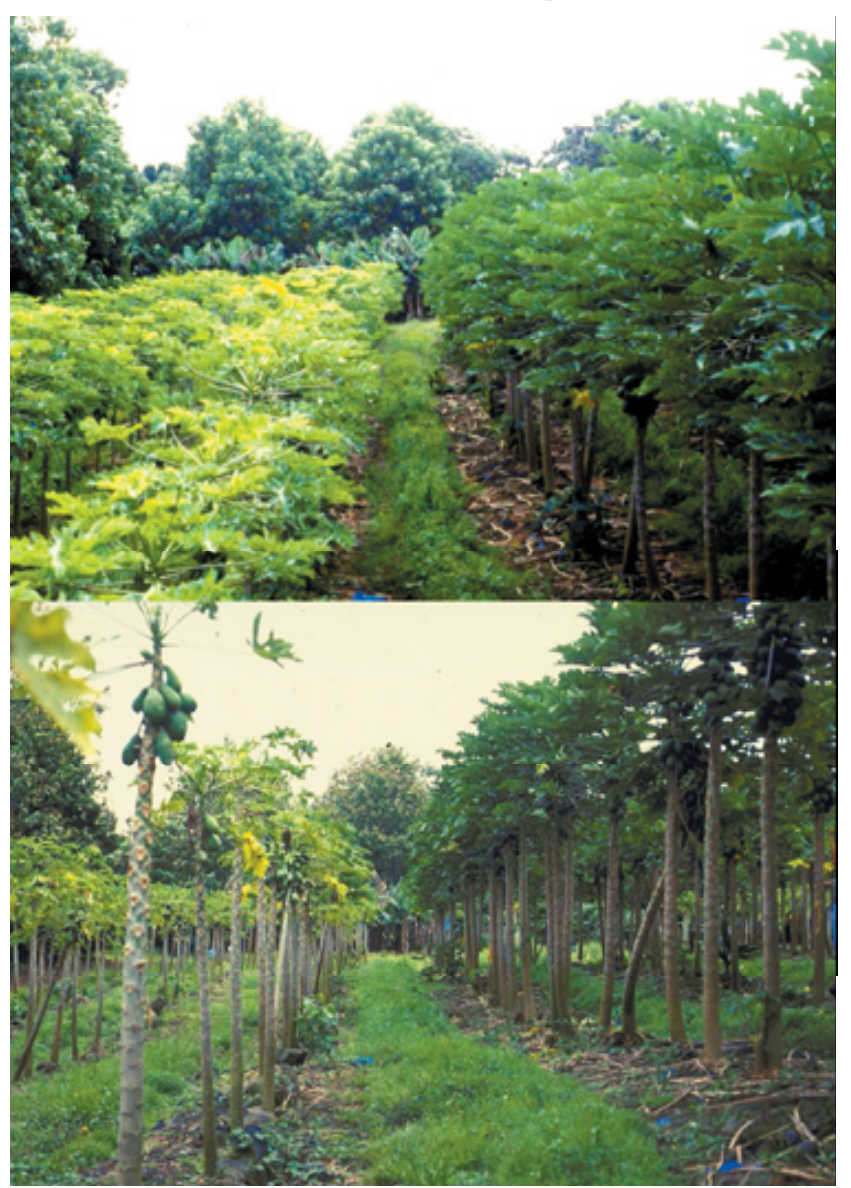

Fig. 3. View of PRSV disease progress in the field test in Puna (Hawaii) at 18 and 23 months (top and bottom, respectively). In each view the susceptible Sunrise variety is shown on the left and resistant transgenic Rainbow on the right (Tripathi et al., 2008) of transgenic fruit tree being commercialized in the world (Fig. 2, 3)

\section{Transgenic papaya in Taiwan}

Other than Hawaii, a CP gene of a native Taiwan strain PRSV YK was used to transform Taiwan papaya cultivars by Agrobacterium mediated transformation (Cheng et al., 1996). The transgenic lines obtained showed various levels of resistance, ranging from delay of symptom development to complete immunity (Bau et al., 2003). Several lines highly resistant to the homologous strain (PRSV YK) provide wide-spectrum resistance to three different geographic strains from Hawaii, Thailand, and Mexico (Bau et al., 2003). During four repeats of field trials from 1996 to 1999 , the transgenic papaya exhibited high degrees of protection against PRSV in Taiwan (Bau et al., 2004). Unfortunately, 18 months after plantation in the fourth field trial, unexpected symptoms of severe distortion on fully expended leaves, stunning on apex, water-soaking on petioles and stem, and yellow ringspot on fruit were noticed on PRSV CP-transgenic papaya plants. The causal agent was distinguished from PRSV by host reactions and serological properties (Bau, 2000) and later identified as Papaya leafdistortion mosaic virus (PLDMV), a potyvirus which originated from Okinawa, Japan, in 1954 (Maoka et al., 1996). All of the PRSV CP transgenic papaya lines were susceptible to PLDMV infection when evaluated under greenhouse conditions. Therefore, in Taiwan, PLD$\mathrm{MV}$ is considered as a serious threat to papaya production once PRSV CP-transgenic papaya is widely applied for the control of PRSV. 
Development of PRSV-resistant transgenic plants faces a major hurdle in achieving resistance against geographically distinct isolates. One of the major reasons of failing to achieve the broad-spectrum PRSV resistance is the involvement of silencing suppressor proteins of viral origin (Ruanjan et al., 2007). For the effective control of PRSV and Papaya leaf-distortion mosaic virus (PLDMV), an untranslatable chimeric construct containing truncated PRSV YK CP and PLDMV P-TW-WF CP genes has been transferred into papaya (Carica papaya cv. 'Thailand') by Agrobacterium-mediated transformation via embryogenic tissues derived from immature zygotic embryos of papaya (Kung et al., 2009). Based on sequence profile of silencing suppressor protein, $\mathrm{HcPro}$, it was that PRSV-HcPro, acts as a suppressor of RNA silencing through micro RNA binding in a dose- dependent manner. In planta expression of PRSV-HcPro affects developmental biology of plants, suggesting the interference of suppressor protein in micro RNA-directed regulatory pathways of plants. Besides facilitating the establishment of PRSV, it showed strong positive synergism with other heterologous viruses as well (Mangrauthia et al., 2010). Therefore, resistance in transgenic papaya can be overcome by PRSV with distant homology to the transgene, or by PRSV strains with HCPro that can sufficiently suppress the silencing mechanism of transgenic papaya. It would therefore be important to develop transgenic papaya that could avoid the impact of these PRSV strains (Tripathi et al., 2008).

\section{Conclusions}

Genetic engineering remains an alternative and rapid method to transfer resistance genes into traditional cultivars, bypassing the long procedure of introgression and the appearance of undesired traits usually associated with it. When traditional breeding can offer cultivars with a medium level of resistance, genetic engineering could provide additional tools to implement virus resistance. In this respect, genetic engineering and traditional breeding are complementary. The availability of protocols for genetic transformation of various important plants like cereals and vegetables has simplified the application of genetic engineering in those crops. Developing broad and durable resistance is the main objective in producing virus resistant transgenic plants. Therefore, as discussed above RNA mediated resistance is more durable and the method of choice for producing virus resistant plants for resistance against new strains of a virus.

\section{References}

Asurmendi, S., R. H. Berga, T. J. Smitha, M. Bendahmane and R. N. Beachy (2007). Aggregation of TMV CP plays a role in $\mathrm{CP}$ functions and in coat-protein-mediated resistance. Virology. 366:98-106.

Bai, Y., Z. Guo, X. Wang, D. Bai and W. Zhang (2009).
Generation of double-virus-resistant marker-free transgenic potato plants. Progress Natural Science. 19:543-548.

Bau, H. J. (2000). Studies on the resistance of transgenic papaya conferred by the coat protein gene of Papaya ringspot virus. PhD Dissertation in Department of Plant Pathology, National Chung Hsing University, Taichung, Taiwan. pp.135.

Bau, H. J., Y. H. Cheng, T. A. Yu, J. S. Yang and S. D. Yeh (2003). Broad spectrum resistance to different geographic strains of Papaya ringspot virus in coat protein gene transgenic papaya. Phytopathology. 93:112-120.

Bau, H. J., Y. H. Cheng, T. A. Yu, J. S. Yang, P. C. Liou, C. H. Hsiao, C. Y. Lin and S. D. Yeh (2004). Field evaluation of transgenic papaya lines carrying the coat protein gene of Papaya ringspot virus in Taiwan. Plant Dis. 88:594-599.

Bendahmane, M., I. Chen, S. Asurmendi, A. A. Bazzini, J. Szecsi and R. N. Beachy (2007). Coat protein-mediated resistance to TMV infection of Nicotiana tabacum involves multiple modes of interference by coat protein. Virology. 366:107116.

Brigneti, G., A. M. Martin-Hernandez, H. Jin, J. Chen, D. C. Baulcombe, B. Baker, J. D. Jones (2004) Virus-induced gene silencing in Solanum species. The Plant Journal. 39:264272.

Brumin, M., S. Stukalov, S. Haviv, M. Muruganantham, Y. Moskovitz, O. Batuman, A. Fenigstein and M. Mawassi (2009) Post-transcriptional gene silencing and virus resistance in Nicotiana benthamiana expressing a Grapevine virus A minireplicon. Transgenic. Res. 18:331-345.

Brunt, A., K. Crabtree, M. Dallwitz, A. Gibbs and L. Watson (1996). Viruses of Plants: Descriptions and Lists from the VIDE Database. C.A.B. International, U.K. pp 1484.

Cao, X., P. Zhou, X. Zhang, S. Zhu, X. Zhong, Q. Xiao, B. Ding and Y. Li (2005). Identification of an RNA silencing suppressors from a plant double stranded RNA virus. Journal of Virology. 79:13018-13027.

Chapman, E. J., A. I. Prokhnevsky, K. Gopinath, V. V. Dolja, J. C. Carrington (2004). Viral RNA silencing suppressors inhibit the micro-RNA pathway at an interphase step. Genes and Development 18:1179-1186.

Chen, J., W. X. Li, D. Xie, J. R. Peng, S. W. Ding (2004). Viral virulence protein suppresses RNA silencing-mediated defense but up regulates the role of microRNA in host gene regulation. Plant Cell. 16:1302-1313.

Cheng, Y. H., J. S. Yang and S. D. Yeh (1996). Efficient transformation of papaya by coat protein gene of Papaya ringspot virus mediated by Agrobacterium following liquidphase wounding of embryogenic tissues with carborundum. Plant Cell Rep. 16:127-132.

Chung, E., E. Seong, Y. C. Kim, E. J. Chung, S. K. Oh, S. Lee, J. M. Park, Y. H. Joung and D. Choi (2004). A method of high frequency virus induced gene silencing in chili pepper Capsicum annuum L. cv. Bukang). Molecular Cell. 17:377380. 
26

Constantin, G. D., B. N. Krath, S. A. MacFarlane, M. Nicolaisen, I. E. Johansen and O. S. Lund (2004). Virus-induced gene silencing as a tool for functional genomics in a legume species. Plant Journal. 40:622-631.

Díaz-Pendón, J. A. and S. W. Ding (2008). Direct and Indirect Roles of Viral Suppressors of RNA Silencing in Pathogenesis. Annual Review of Phytopathology. 46:303-326.

Ding, X. S., W. L. Schneider, S. R. Chaluvadi, R. M. Rouf Mian and R. S. Nelson (2006). Characterization of a Brome mosaic virus strain and its use as a vector for gene silencing in monocotyledonous hosts. Molecular Plant Microbe Interaction. 19:1229-1239.

Faivre-Rampant, O., E. M. Gilroy, K. Hrubikova, I. Hein, S. Millam, G. J. Loake, P. Birch, M. Taylor, C. Lacomme (2004). Potato virus $\mathrm{X}$-induced gene silencing in leaves and tubers of potato. Plant Physiology. 134:1308-1316.

Ferreira, S. A., K. Y. Pitz, R. Manshardt, F. Zee, M. M. Fitch and D. Gonsalves (2002). Virus coat protein transgenic papaya provides practical control of papaya ringspot virus in Hawaii. Plant Disease. 86:101-105.

Fitch, M. M. M. and R. M. Manshardt (1990). Somatic embryogenesis and plant regeneration from immature zygotic embryos of papaya (Carica papaya L.). Plant Cell Rep. 9:320- 324.

Fitch, M. M. M., R. M. Manshardt, D. Gonsalves, J. L. Slightom and J. C. Sanford (1990). Stable transformation of papaya via microprojectile bombardment. Plant Cell Rep. 9:189194.

Fofana, I. B., A. Sangare, R. Collier, C. Taylor and C. M. Fauquet (2004). A geminivirus-induced gene silencing system for gene function validation in cassava. Plant Molecular Biology. 56: 613-624.

Fuchs, M. and D. Gonsalves (2007). Safety of virus-resistant transgenic plants two decades after their introduction: Lessons from realistic field risk assessment studies. Ann. Rev. Phytopathology. 45:173-202.

Furutani, N., S. Hidaka, Y. Kosaka, Y. Shizukawa and S. Kanematsu (2006). Coat protein gene-mediated resistance to soybean mosaic virus in transgenic soybean Breeding Science. 56:119-124.

Gonsalves, D. (2002). Coat protein transgenic papaya "acquired” immunity for controlling papaya ringspot virus. Curr. Top. Microbiol. Immunol. 266:73-83.

Gossele, V. V., I. I. Fache, F. Meulewaeter, M. Cornelissen and M Metzlaff (2002). SVISS-a novel transient gene silencing system for gene function discovery and validation in tobacco. The Plant Journal 32: 859-866.

Gould, B. and E. M. Kramer (2007). Virus-induced gene silencing as a tool for functional analyses in the emerging model plant Aquilegia (columbine, Ranunculaceae). BMC Plant Methods. 12: 6.

Hamilton, A. J. and D. C. Baulcombe (1999). A species of small antisense RNA in posttranscriptional gene silencing in plants. Sci. 286:950-952.

Herr, A. J. (2005). Pathways through the small RNA world of plants. FEBS (Fed Eur Biol Soc) Lett. 579:5879-5888.

Hileman, L. C., S. Drea, G. Martino, A. Litt, V. F. Irish (2005). Virus induced gene silencing is an effective tool for assaying gene function in the basal eudicot species Papaver somniferum (opium poppy). The Plant Journal. 44:334-341.

Holzberg, S., P. Brosio, C. Gross and G. P. Pogue (2002). Barley stripe mosaic virus-induced gene silencing in a monocot plant. Plant Journal. 30:315-327.

Hou, H. W. Qiu (2003). A novel co-delivery system consisting of a tomato bushy stunt virus and a defective interfering RNA for studying gene silencing. Journal of Virology Methods. 111:37-42.

Kawazu, Y., F. Ryoi and N. Yuji (2009).Transgenic resistance to Mirafiori lettuce virus in lettuce carrying inverted repeats of the viral coat protein gene. Transgenic. Res. 18:113-120.

Kawazu, Y., R. Fujiyama, K. Sugiyama and T. Sasaya (2006). A transgenic lettuce line with resistance to both Lettuce bigvein associated virus and Mirafiori lettuce virus. J Am Soc Hortic Sci. 131:760-763.

Kouassi, N. K., L. Chen, C. Siré, M. Bangratz-Reyser, R. N. Beachy, C. M. Fauquet and C. Brugidou (2006). Expression of rice yellow mottle virus coat protein enhances virus infection in transgenic plants. Archives Virology.151:21112122.

Kumagai, M. H., J. Donson, G. Della-Cioppa, D. Harvey, K. Hanley and L. K. Grill (1995). Cytoplasmic inhibition of carotenoid biosynthesis with virus-derived RNA. Proc. Natl. Acad. Sci. USA 92:1679-1683.

Kung, Y. J., T. A. Yu, C. H. Huang, H. C. Wang, S. L. Wang and S. D. Yeh (2009). Generation of hermaphrodite transgenic papaya lines with virus resistance via transformation of somatic embryos derived from adventitious roots of in vitro shoots. Transgenic Res (In press).

Kunik, T., R. Salomon, D. Zamir, N. Navot, M. Zeidan, I. Michelson, Y. Gafni and H. Czosnek (1994). Transgenic tomato plants expressing the tomato yellow leaf curl virus capsid protein are resistant to the virus. Biotechnology. 12: 500-504.

Lee, Y. H., M. Jung, S. H. Shin, J. H. Lee, S. H. Choi , N. H. Her, J. H. Lee, K. H. Ryu, K. Y. Paek and C. H. Harn (2009). Transgenic peppers that are highly tolerant to a new CMV pathotype. Plant Cell Rep. 28:223-232.

Li, F. and S. W. Ding (2006). Virus counter defense: diverse strategies for evading the RNA silencing immunity. Annual Review of Microbiology. 60:503-531.

Ling, K., S. Namba, C. Gonsalves, J. L. Slightom and D. Gonsalves (1991). Protection against detrimental effects of potyvirus infection in transgenic tobacco plants expressing the Papaya ringspot virus coat protein gene. Bio/Technology. 9:752-758.

Ling, K. S., H. Y. Zhu and D. Gonsalves (2009). Resistance 
to Grapevine leafroll associated virus-2 is conferred by post-transcriptional gene silencing in transgenic Nicotiana benthamiana.Transgenic Res.17:733-740.

Liu, Y., M. Schiff, R. Marathe and S. P. Dinesh-Kumar (2002). Tobacco Rarl, EDS1 and NPRI/NIMI like genes are required for $N$ mediated resistance to tobacco mosaic virus. The Plant Journal. 30:415-429.

Lius, S., R. M. Manshardt, M. M. M. Fitch, J. L. Slightom, J. C. Sanford and D. Gonsalves (1997). Pathogen-derived resistance provides papaya with effective protection against Papaya ringspot virus. Mol. Breed. 3:161-168.

Lomonossoff, G. P. (1995). Pathogen-derived resistance to plant viruses. Annual review of Phytopathology. 33:323-343.

Mangrauthia S. K., P. Singh and S. Praveen (2010). Genomics of Helper Component Proteinase Reveals Effective Strategy for Papaya Ringspot Virus Resistance. Molecular Biotechnology. 44:22-29.

Maoka, T., S. Kashiwazaki, S. Tsuda, T. Usugi and H. Hibino (1996). Nucleotide sequence of the capsid protein gene of the Papaya leaf-distortion mosaic potyvirus. Arch. Virol. 141:197-204.

Merai, Z., Z. Kerenyi, A. Molnar, E. Barta, A. Valcozi, G. Bistray, Z. Havelda, J. Burgyan and D. Silhavy (2005). Aureusvirus P14 is an efficient RNA silencing suppressor that binds double stranded RNAs without size specificity. Journal of Virology. 79:7217-7226.

Mlotshwas, S., O. Voinnet, M. F. Mette, M. Matzke, H. Vaucheret, S. W. Ding, G. Pruss and G. B. Vance (2002). RNA silencing and its mobile silencing signal. The Plant Cell. 14: 289-301.

Murphy, F. A., C. M. Fauquet, D. H. L. Bishop, S.A. Ghabrial, A.W. Jarvis, G. P. Martelli, M. A. Mayo and M. D. Summer (1995). Virus Taxonomy. Springer-Verlag, Vienna. pp.350354.

Naylor, M., J. Reeves, J. I. Cooper, M. L. Edwards and H. Wang (2005). Construction and properties of a gene-silencing vector based on Poplar mosaic virus (genus Carlavirus). Journal of Virology Methods. 124:27-36.

Niu, Q. W., S. S. Lin, J. L. Reyes, K. C. Chen, H. W. Wu, S. D. Yeh and N. H. Chua (2006). Expression of artificial microRNAs in transgenic Arabidopsis thaliana confers virus resistance. Nature Biotechnology. 24:1420-1428.

Novina, C. D., M. F. Murray, D. M. Dykxhoorn, P. J. Beresford, J. Riess, S. K. Lee, R. G. Collman, J. Lieberman, P. Shanker, P. A. Sharp (2002). siRNA-directed inhibition of HIV-1 infection. Nature Mediterranean. 8:681-686.

Peele, C., C. V. Jordan, N. Muangsan, M. Turnage, E. Egelkrout, P. Eagle, L. Hanley-Bowdoin and D. Robertson (2001). Silencing of a meristematic gene using geminivirus-derived vectors. Plant Journal. 27:357-366.

Pooggin, M., P. V. Shivaprasad, K. Veluthambi and T. Hohn (2003). RNAi targetting of DNA viruses. Nature Biotechnology. 2:131-32.

Powell-Abel, P., R. S. Nelson, B. De, N. Hoffmann, S.G. Rogers,
27

R. T. Fraley and R. N. Beachy (1986). Delay of disease development in transgenic plants that express the tobacco mosaic virus coat protein gene. Sci. 232:738-743.

Praveen, S., S. V. Ramesh, A. K. Mishra, V. Koundal and P. Palukaitis (2010). Silencing potential of viral derived RNAi constructs in Tomato leaf curl virus-AC4 gene suppression in tomato. Transgenic. Res. 19: 45-55.

Qu, J., J. Ye and R. X. Fang (2007). Artificial microRNAmediated virus resistance in plants. Journal of Virology. 81: 6690-6699.

Ratcliffe, F. G., S. A. MacFarlane and D. C. Baulcombe (1999). Gene silencing without DNA: RNA-mediated crossprotection between viruses. Plant Cell. 11:1207-1215.

Ratcliff, F., A. M. Martin-Hernandez and D. C. Baulcombe (2001). Tobacco rattle virus as a vector for analysis of gene functions by silencing. Plant Journal. 25: 237-245.

Rojas, M.R., H. Jiang, R. Salati, B. Xoconostle-Cazares, M. R. Sudarshana, W. J. Lucas and R. L. Gilbertson (2001). Functional analysis of proteins involved in movement of the monopartite begomovirus, tomato yellow leaf curl virus. Virology. 291:110-125.

Ruanjan, P., S. Kertbundit and M. Juříček (2007). Posttranscriptional gene silencing is involved in resistance of transgenic papayas to papaya ringspot virus. Biol. plant.51:517-520.

Ruiz, M. T., O. Voinnet and D. C. Baulcombe (1998). Initiation and maintenance of virus-induced gene silencing. Plant Cell 10:937-946.

Ruiz-Ferrer, V. and O. Voinnet (2007). Viral suppression of RNA silencing: $2 \mathrm{~b}$ wins the golden fleece by defeating argonaute. Bioassays. 29:319-323.

Scofield, S. R., L. Huang, A. S. Brandt and B. S. Gill (2005). Development of a virus-induced gene silencing system for hexaploid wheat and its use in functional analysis of the Lr21-mediated leaf rust resistance pathway. Plant Physiology 138:2165-2173.

Takeda, A., M. Tsukuda, H. Mizumoto, K. Okamoto, M. Kaido, K. Mise and T. Okuno (2005). A pant RNA virus suppressor RNA silencing through RNA replication. The EMBO Journal. 24:3147-3157.

Tao, X. and X . Zhou (2004). A modified viral satellite DNA that suppresses gene expression in plants. The Plant Journal 38:850-860.

Tripathi, S. J. Y. Suzuki, S. A. Ferreira and D. Gonsalves (2008). Papaya ringspot virus-P: characteristics, pathogenicity, sequence variability and control. Molecular plant pathology. 9:269-280.

Turnage, M. A., N. Muangsan, C. G. Peele and D. Robertson (2002). Geminivirus-based vectors for gene silencing in Arabidopsis. The Plant Journal. 30:107-117.

Tyagi, H., S. Rajasubramaniam, M. V. Rajam and I. Dasgupta (2008). RNA-interference in rice against Rice tungro bacilliform virus results in its decreased accumulation in 
28 inoculated rice plants. Transgenic. Res. 17:897-904.

Ullu, E., A. Djikeng, H. Shi and C. Tschudi (2002). RNA interference: advances and questions. Philosophical Transactions of the Royal Society of London British Biological Science. 29: 65-70.

Vance, V. and H. Vaucheret (2001). RNA silencing in plantsdefense and counter-defense. Proc. Natl. Acad. Sci. USA 292:2277-2280.

Vanitharani, R., P. Chellappan and C. M. Fauquet (2003). Short interfering RNA-mediated interference of gene expression and viral DNA accumulation in cultured plant cells. Proc. Natl. Acad. Sci. USA. 100:9632-9636.

Vasudevan, A., T. K. Oh, J. S. Park, S. V. Lakshmi, B. K. Choi, S. H. Kim, H. J. Lee, J. Ji, J. H. Kim, A. Ganapathi, S. C. Kim and C. W. Choi (2008). Characterization of resistance mechanism in transgenic Nicotiana benthamiana containing Turnip crinkle virus coat protein. Plant cell reports. 27:17311740.

Wang, C. H. and S. D. Yeh (1997). Divergence and conservation of the genomic RNAs of Taiwan and Hawaii strains of Papaya ringspot virus. Arch. Virol. 142:271-285.
Waterhouse, P. M., M. W. Graham, M. B. Wang (1998). Virus resistance and gene silencing in plants can be induced by simultaneous expression of sense and antisense RNA. Proc. Natl. Acad. Sci. USA 95:13959-13964.

Waterhouse, P. M., M. B. Wang and T. Lough (2001). Gene silencing as an adaptive defense against viruses. Nature. 411: 834-842.

Yeh, S. D. and D. Gonsalves (1994). Practices and perspective of control of papaya ringspot virus by cross protection. Adv. Dis. Vector Res. 10:237-257.

Yeh, S. D., F. J. Jan, C. H. Chiang, T. J. Doong, M. J. Chen, P. H. Chung and H. J. Bau (1992). Complete nucleotide sequence Vand genetic organization of Papaya ringspot virus RNA. J Gen. Virol. 73:2531-2541.

Yu, H. and P. P. Kumar (2003). Post-transcriptional gene silencing in plants by RNA. Plant Cell Rep. 22:167-174.

Zanek, M. C., C. A. Reyes, M. Cervera, E. J. Peña, K. Velázquez, N. Costa, M. I. Plata, O. Grau, L. Peña and M. L. García (2008). Genetic transformation of sweet orange with the coat protein gene of Citrus psorosis virus and evaluation of resistance against the virus. Plant Cell Reports. 27:57-66. 